\title{
Pyroclasts of the First Phases of the Explosive-Effusive PCCVC Volcanic Eruption: Physicochemical Analysis
}

\author{
Lia Botto ${ }^{*}$, Vicente Barone ${ }^{1}$, María E. Canafoglia ${ }^{1}$, Elizabeth Rovere ${ }^{2}$, Roberto Violante ${ }^{3}$, \\ María J. González ${ }^{1,4}$, Delia Gazzoli ${ }^{5}$, Isidoro Schalamuk ${ }^{4}$ \\ ${ }^{1}$ CEQUINOR (CCT-La Plata-CONICET-UNLP), La Plata, Argentina \\ ${ }^{2}$ Servicio Geológico Minero Argentino SEGEMAR, Buenos Aires, Argentina \\ ${ }^{3}$ Servicio de Hidrografía Naval, División Geología y Geofísica Marina, Buenos Aires, Argentina \\ ${ }^{4}$ INREMI (CICPBA-UNLP), La Plata, Argentina \\ ${ }^{5}$ Dipartimento di Chimica, Universita di Roma La Sapienza, Roma, Italy \\ Email: *botto@quimica.unlp.edu.ar
}

Received 29 June 2015; accepted 7 August 2015; published 10 August 2015

Copyright (C) 2015 by authors and Scientific Research Publishing Inc.

This work is licensed under the Creative Commons Attribution International License (CC BY). http://creativecommons.org/licenses/by/4.0/

(c) (i) Open Access

\section{Abstract}

The morphology, texture, grain size and other physicochemical characteristics of pyroclastic material from the first phases of the Puyehue-Cordon Caulle volcanic complex (PCCVC) eruption, (Southern Andes, Chile), can be associated to the model recently reported for the magma storage and its ascent conditions. The eruption started June $4^{\text {th }} \mathbf{2 0 1 1}$, and the studied volcanic material corresponds to that collected in Argentine territory at different distances from the source, between 4 and 12 June 2011. The explosive-effusive volcanic process of the first days occurred with the simultaneous emplacement of lava flows and the venting of pyroclastic material, ejecting two well differentiated types of particles. The more abundant was constituted by rhyolitic and light color pumice fragments, characterized by a typical vesicular texture, easy fragmentation and absence of occluded crystalline phases. Particles found in minor proportion were dark color, different in shape and texture and rich in Fe and Ti. They seemed to be more effective for the interaction with emitted gases in the upper part of the column, for this reason, they appeared partially covered by condensation products. The ascent conditions of the magma affected its rheological behavior through variations in the degassing, viscosity and fragmentation. On the other hand, distance to the source, depositional time, volcanic evolution and environmental conditions are factors that affect the chemical composition of collected ash. So, the $\mathrm{SiO}_{2} / \mathrm{FeO}$ ratio not only increases with the distance but also with the deposition time and volcanic activity. The work was done with the aid of several techniques such as a laser-sediment analyzer, X-ray diffraction (XRD), chemical analysis (bulk and surface), SEM microscopy and Raman "microprobe" spectroscopy. On the other hand,

\footnotetext{
${ }^{*}$ Corresponding author.
}

How to cite this paper: Botto, L., Barone, V., Canafoglia, M.E., Rovere, E., Violante, R., González, M.J., Gazzoli, D. and Schalamuk, I. (2015) Pyroclasts of the First Phases of the Explosive-Effusive PCCVC Volcanic Eruption: Physicochemical Analysis. Advances in Materials Physics and Chemistry, 5, 302-315. http://dx.doi.org/10.4236/ampc.2015.58030 
the physicochemical behavior of the pyroclastic material allows us to suggest eventual applications.

\section{Keywords}

Pyroclastic Materials, Chemical Composition, Mineralogy, Sem Microscopy, Raman Spectroscopy

\section{Introduction}

The Puyehue-Cordon Caulle volcanic complex (PCCVC) locates at 40 34'57"S - 72 06'3"W, 2236 masl, Chile is part of the southern Andes system at the Western South America [1]. Numerous earthquakes and eruptions occur in volcanoes located at the border between Chile and Argentina; the dominance of regional "westerly" winds has been responsible for transport, dispersion and accumulation of tephras along the eastern mountain chain, in Argentine territory [2]. In this context, the last eruptive activity of the PCCVC started on June $4^{\text {th }} 2011$ produced large deposits of pyroclastic material in northern Patagonia and southern Pampas in Argentina [3] [4]. After the first week of eruption tephra-fall accumulation affected $\sim 8 \times 10^{6}$ hectares in the countryside of Argentina.

It is well known that a volcanic plume of an explosive eruption is a mixture of gas, fragmented silicates and aerosols derived from the magmatic emissions and background air [5]. Volcanic ash, referred as pyroclasts with $\mathrm{D}<2 \mathrm{~mm}$, can be distinguished between coarse material (size between $64 \mu \mathrm{m}$ and $2 \mathrm{~mm}$ ) and dust (D lower than $64 \mu \mathrm{m}$ ) [6]. The plume evolution is verified by transport and dispersion models [7] and the size and shape of particles are critical for their transport and sedimentation. The finest particles $(<10 \mu \mathrm{m})$, conventionally defined in terms of the aerodynamic diameter, are crucial for human health [8] [9].

In general, the morphology and characteristics of pyroclastic falls are controlled by a complex array of factors, particularly the magma rheology, which is in turn, governed by the composition of major element, bubble content, temperature, viscosity, shear rate, etc. [6] [10] [11]. A schematic interpretation of the storage and eruption of near-liquidus rhyolite magma at Cordon Caulle volcano is recently reported on the basis of the behavior of volcanic events in Southern Andes during last decades [12]. So, the mineral assemblage and glass chemistry for the PCCVC eruption are analyzed and experimentally reproduced at a micro scale by Castro et al. [12]. Hence, the morphology, texture and chemical composition of pyroclasts are properties that can contribute to understand the heterogeneity of the PCCVC explosive-effusive process, which is observed with the emplacement of lava flows during the volcanic venting [12] [13]. In this context, this paper presents physicochemical characterization of fresh ash (without weathering effects), collected in Argentina territory at different distances of the source during the first week of eruption. Techniques as grain-size distribution by a laser-sediment analyzer, $\mathrm{X}$-ray diffraction (XRD), chemical analysis, SEM microscopy and Raman "microprobe" spectroscopy were used. Likewise, the comparison with material collected five months after the original event has also been done to evaluate environmental alteration effects and deposited material quality.

\section{Materials and Methods}

The PCCVC is a large NW-SE volcanic chain. Characteristics of 2011 eruption were reported by Special Reports of SERNAGEOMIN (Chilean Geological Survey) [3].

Table 1 shows samples that have been collected at SE and E-SE directions from the source in Argentina territory, whereas Figure 1 shows the location of the sampling spots, where the areas of ash accumulated are indicated. Samples are named Mdh (M: locality, d: day and h: hour of sampling at the same day). B4h to B7 samples belong to Bariloche, Rio Negro Province, whereas LAd proceeds from Villa La Angostura, Neuquen Province and PMd from Puerto Madryn, Chubut Province. All of them correspond to the first days of higher volcanic activity (June $4^{\text {th }}$ to $8^{\text {th }}$ ). Instead, samples B10 and B12 (from Bariloche) were collected after a new reactivation of the volcanic activity occurred after June $9^{\text {th }}$. Finally, the sample identified as LANov2011 was collected 5 month after the first volcanic episode, from the accumulated ash-falls in the golf course of Villa La Angostura. Samples were collected by using spatula and plastic bags. Further, they were kept in desiccators until they were subjected to chemical and physical measurements.

Bulk samples without any previous treatment were wet-sieved for analyzing the grain-size distribution, using 


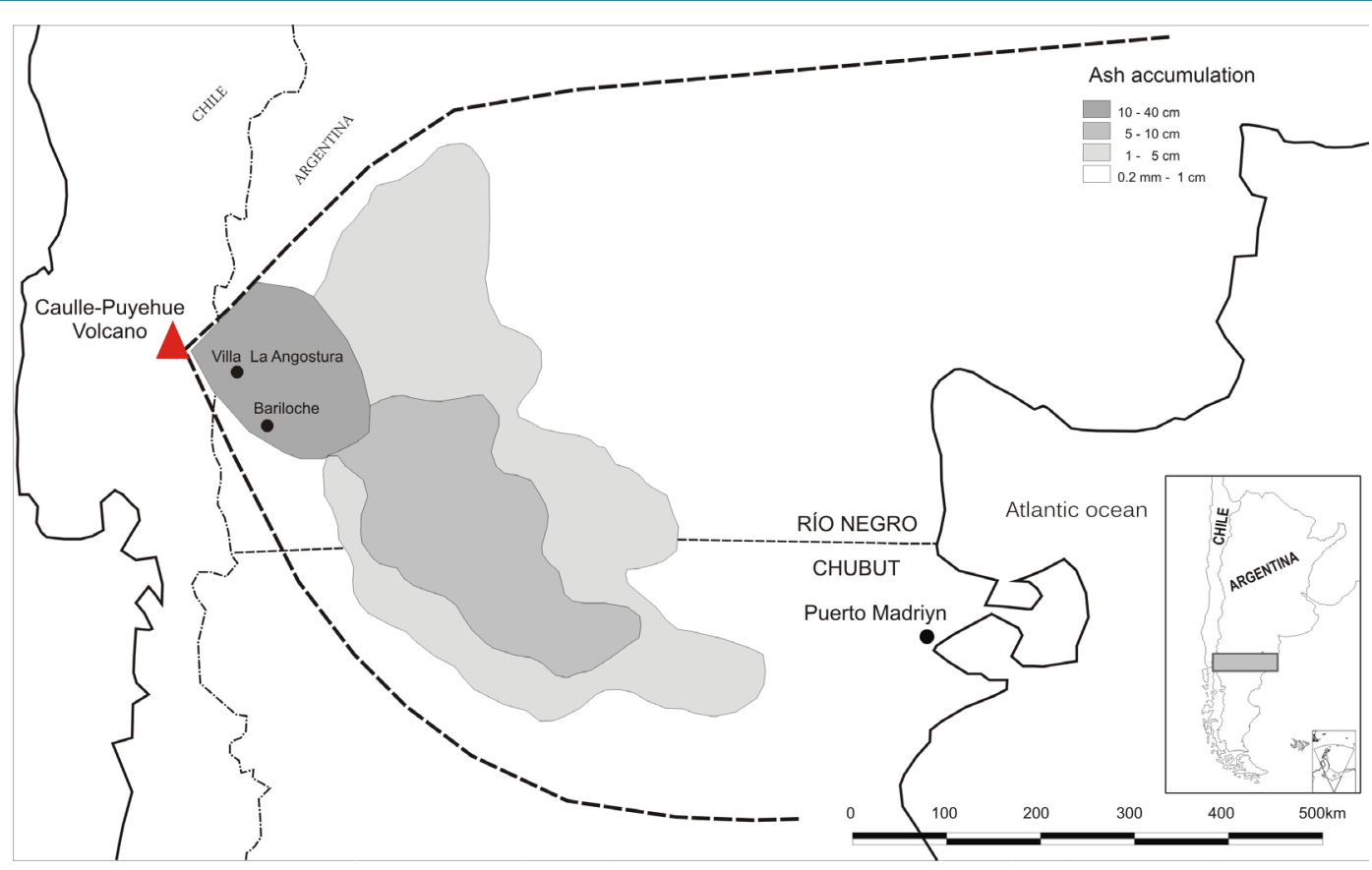

Figure 1. Studied areas according to Table 1 (Villa La Angostura, Bariloche and Puerto Madryn). Ash accumulations are included (simplified from Bermúdez and Delpino [14]).

Table 1. Data of Pyroclastic sampling.

\begin{tabular}{|c|c|c|c|c|}
\hline Sample & Locality & Location & Distance from the source $(\mathrm{Km})$ & Sampling Date \\
\hline B4.18 & Bariloche & $\begin{array}{l}41^{\circ} 03^{\prime} 54^{\prime \prime S} \\
71^{\circ} 29^{\prime} 11^{\prime \prime W}\end{array}$ & 75 & $\begin{array}{c}2011 \\
\text { June } 4^{\text {th }} 18 \mathrm{~h}\end{array}$ \\
\hline B4.20 & “ & “ & “ & $\begin{array}{c}\text { June } 4^{\text {th }} \\
20 \mathrm{~h}\end{array}$ \\
\hline B4.23 & “ & “ & “ & $\begin{array}{c}\text { June } 4^{\text {th }} \\
23 \mathrm{~h}\end{array}$ \\
\hline B7 & “ & “ & “ & June $7^{\text {th }}$ \\
\hline B10 & “ & “ & “ & June $10^{\text {th }}$ \\
\hline B12 & “ & “ & “ & June $12^{\text {th }}$ \\
\hline LA5 & Villa La Angostura & $\begin{array}{c}40^{\circ} 45^{\prime} 48^{\prime \prime S} \\
71^{\circ} 38^{\prime} 46^{\prime \prime} \mathrm{W}\end{array}$ & 40 & June $5^{\text {th }}$ \\
\hline PM6 & Puerto Madryn & $\begin{array}{l}42^{\circ} 45^{\prime} 46^{\prime \prime S} \\
65^{\circ} 02^{\prime} 12^{\prime \prime} \mathrm{W}\end{array}$ & 635 & June $6^{\text {th }}$ \\
\hline LANov.2011 & Villa La Angostura & $\begin{array}{l}40^{\circ} 47^{\prime} 04^{\prime \prime S} \\
71^{\circ} 38^{\prime} 14^{\prime \prime} \mathrm{W}\end{array}$ & 40 & Nov 2011 \\
\hline
\end{tabular}

Mdh where $\mathrm{M}$ = locality, $\mathrm{d}$ = day of sampling, $\mathrm{h}$ = hour for the sampling at the same day.

a laser-sediment analyzer Malvern-model Mastersizer Hydro 2000-(INCITAP, University of La Pampa). Likewise, samples were dry-sieved by manual and mechanic (sonic sifter) methods, in order to compare the dry and wet results (disaggregation in water as well as release of particles trapped in vesicles). Although a quantitative comparison between wet and dry analysis cannot be done since both methodologies involve different types of results (percentages expressed in volume in the wet analysis and in weight in the dry analysis), a qualitative comparison was possible considering a basic "homogeneous" composition of samples.

Scanning Electron Microscopy and Electron Diffraction Spectroscopy (SEM-EDS) measurements were performed in an ESEM (FEI Quanta 200), with tungsten filament and an ETD (high Vacuum secondary electron detector) (LIMF Lab., University of La Plata). Microanalysis was carried out with an EDAX Detector Apollo 40. Chemical results were expressed as \% oxides. Particles differenced by morphological aspect, color and size were 
hand-picked selected under binocular microscope. Likewise, particles showing surface coating were analyzed after stirring with water for $5 \mathrm{~min}$ (to eliminate adhered and adsorbed substances to the surface).

X-ray diffraction patterns for mineralogical analysis were carried out in a PHILIPS PW 1710 diffractometer, $\mathrm{CuK} \alpha$ radiation and Ni filter (LANADI Lab. University of La Plata). Patterns were registered between $10^{\circ}-60^{\circ}$ of $2 \theta\left(1^{\circ}\right.$ of $\left.2 \theta / \mathrm{min}\right)$.

Raman spectroscopic analyses were carried out with in Via Renishaw micro-RAMAN spectrometer equipped with an air-cooled CCD detector and edge filters. A $785.0 \mathrm{~nm}$ emission line from a diode laser was focused on the sample by a Leica DLML microscope, using $5 \times$ or $20 \times$ objectives. The power of the incident beam was about $5 \mathrm{~mW}$. Five $10 \mathrm{~s}$ accumulations were generally acquired for each sample. The resolution was $2 \mathrm{~cm}^{-1}$ and spectra were calibrated using the $520.5 \mathrm{~cm}^{-1}$ line of a silicon wafer. Spectral analysis was done by background subtraction and curve fitting.

\section{Results and Discussion}

From macro- and optical microscopic observation, particles collected in places located at different distances from the source the first days of the PCCVC eruption have different sizes, shapes, colors and morphologies. Although the glassy material was the main component of the mixture, as it is observed in other volcanic eruptions, it depends on geographic, meteorological and volcanic factors [7], and the observed differences could be correlated with the magma storage and its ascent conditions. In this sense, the experimental reproduction of the mineral assemblage and glass-chemistry in PCCVC magma, reported by Castro et al. [12], has proved to be useful in classifying the ashfall.

Literature reports patters of pressure and temperature ( 100 MPa, $\left.900^{\circ} \mathrm{C}\right)$ for a shallowly stored magma ( 5 $\mathrm{Km})$ and two paths for the ascent and decompression: by a shorter vertical conduit and by a longer dike-type lateral flow field [12] [13] [15]. The effect of these geometries on the magma rheology affects transport conditions leading to variations in size, color, composition, fracture and texture of t6he ejected material.

Sedimentological parameters for Bariloche samples clearly show two distinct episodes of grain-size tendencies, both with similar sequences, what is coincident with the occurrence of different eruptive phases [3] as shown in Table 2 and Figure 2. The pyroclastic material from the initial eruptive event (B4-B7) was characterrized, at the beginning, by more than $70 \%$ of sand with predominance of coarse and medium sand fractions and subordinate amounts of fine material, in agreement with the reported seismic intensity (volcanic explosivity index VEI = 5) and with meteorological aspects (plume direction S-SE). At the end of this event (B7) the amount of fines broadly equalized that of the sand, which was in turn finer than the original sandy fraction. For the second event initiated on June $9^{\text {th }}$ (B10-B12 samples), although the eruption activity was lower (VEI = 3) and a rotation of the plume was denounced (between $55^{\circ} \mathrm{W}-70^{\circ} \mathrm{W}$ [7]), sedimentological parameters of analyzed materials showed a similar behavior as that of the first event, that is, a predominance of sand at the beginning and an increase in fines at the end. Except for sample B7 representing the end of the initial eruptive event, bi-

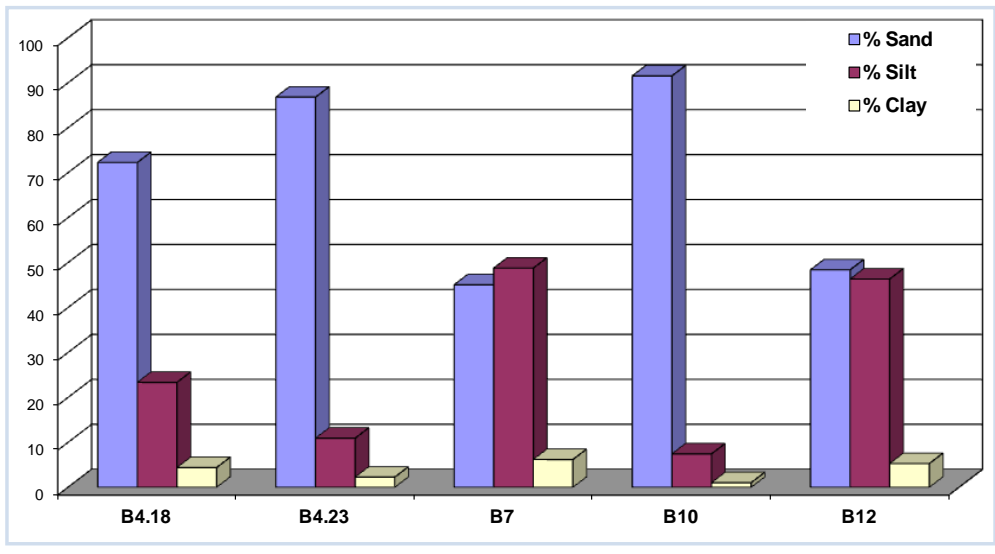

Figure 2. Grain size of sand, silt and clay fractions (\%) for Bariloche samples collected June $4^{\text {th }}(18$ and $23 \mathrm{~h})$ named B4.18 and B4.23, and June $7^{\text {th }}, 10^{\text {th }}$ and $12^{\text {th }}$. 
Table 2. Grain size analyses performed by the "wet-sieving” method.

\begin{tabular}{|c|c|c|c|c|c|}
\hline & B4.18 & B4.23 & B7 & B10 & B12 \\
\hline$\underline{\operatorname{Mz}(\varphi)}$ & 2.61 & 1.36 & 4.31 & 0.67 & 3.99 \\
\hline $\begin{array}{l}\text { Character of grain-size } \\
\text { distribution }\end{array}$ & Bimodal & Bimodal & Unimodal & Bimodal & Bimodal \\
\hline Mode (interval) $(\varphi)$ & $0.5-1$ & $1-1.5$ & $4.5-5$ & $0-0.5$ & $4.5-5$ \\
\hline $2^{\text {nd }}$ mode (interval) $(\varphi)$ & $5.5-6$ & $6-6.5$ & & $3.5-4$ & $1.5-2$ \\
\hline$\%$ Sand & 72.27 & 86.81 & 45.04 & 91.53 & 48.38 \\
\hline$\%$ Silt & 23.35 & 10.93 & 48.77 & 7.44 & 46.34 \\
\hline$\%$ Clay & 4.38 & 2.26 & 6.19 & 1.02 & 5.28 \\
\hline \% Fines (silt + clay) & 27.73 & 13.19 & 54.96 & 8.46 & 51.62 \\
\hline \multicolumn{6}{|l|}{ \% Sand by size: } \\
\hline Coarse sand & 30.44 & 35.46 & 1.35 & 68.75 & 6.98 \\
\hline Medium sand & 28.46 & 44.18 & 9.5 & 18.31 & 13.17 \\
\hline Fine sand & 5.43 & 4.97 & 14.35 & 1.57 & 11.85 \\
\hline Very fine sand & 4.51 & 1.33 & 19.83 & 2.9 & 16.38 \\
\hline \multicolumn{6}{|l|}{ \% Silt by size: } \\
\hline Coarse silt & 5.89 & 2.81 & 21.03 & 2.55 & 18.87 \\
\hline Fine silt & 17.46 & 8.12 & 27.74 & 4.89 & 27.47 \\
\hline
\end{tabular}

modal distribution with a strong asymmetry in the coarse fraction was evidenced, with predominance of sand fraction and a large tail of subordinate finer fractions in the silt and clay range.

Tendencies in grain-size evolution during the two events indicated an initial episode of dominating coarse fraction (sand), and then an increase in fines. It is considered that the original erupted ash contained similar amounts of sand and fines, but the coarser fractions were rapidly deposited (this is the reason why sand dominated in initial deposits) and finally, at the cycle end, the fine fraction that had a longer permanence period in the air was deposited together with the remaining finest sandy fractions.

Different particles were selected from Bariloche coarser fraction, taking into account size, morphology and color, in order to be observed by SEM microscopy. Volcanic glass light-color (VGLC) was the predominant fraction, represented by particles ranged between $1000-1500 \mu \mathrm{m}$, although specimens with larger size were also observed. VGLC was characterized by a large number of pipe-like vesicles of thin wall, grooves and fluidal texture, as shown in SEM micrograph of Figure 3(a). The average EDS chemical analysis of VGLC material is given in Table 3.

The composition of B4 bulk material and fine crystals is included in the former and last columns.

Associated to kinematic process, a lower percentage of dark-color particles (DP) was observed in the collected ashes. DP particles showed shape and texture different to those observed for the colorless ones (VGLC) as it is shown in Figure 3(b), where vesicular texture (spherical form) and droplet shape grains are noticed. This material was produced together with dark fragments of older volcanic rocks ripped by magma from the conduit walls during its ascent in the explosive phase. The formation of DP particles could be associated to a low-viscosity of magma. The grain size was not larger than $1000 \mu \mathrm{m}$. Both, the wall thickness and the size of vesicles were larger than those observed for the VGLC glass. Average EDS chemical data are given in Table 3.

Other particles, similar in size and shape to the DP ones, presented smooth surfaces (Figure 3(c)). Morphological differences could be attributed to the partial covering of the surface by condensation effects, for this reason they were identified as covered particles (CP). They could be related to a fast solidification by a quenching process allowing the condensation of products on the surface from the interaction with emitted gases in the magmatic column. Chemical analysis is included in Table 3. 

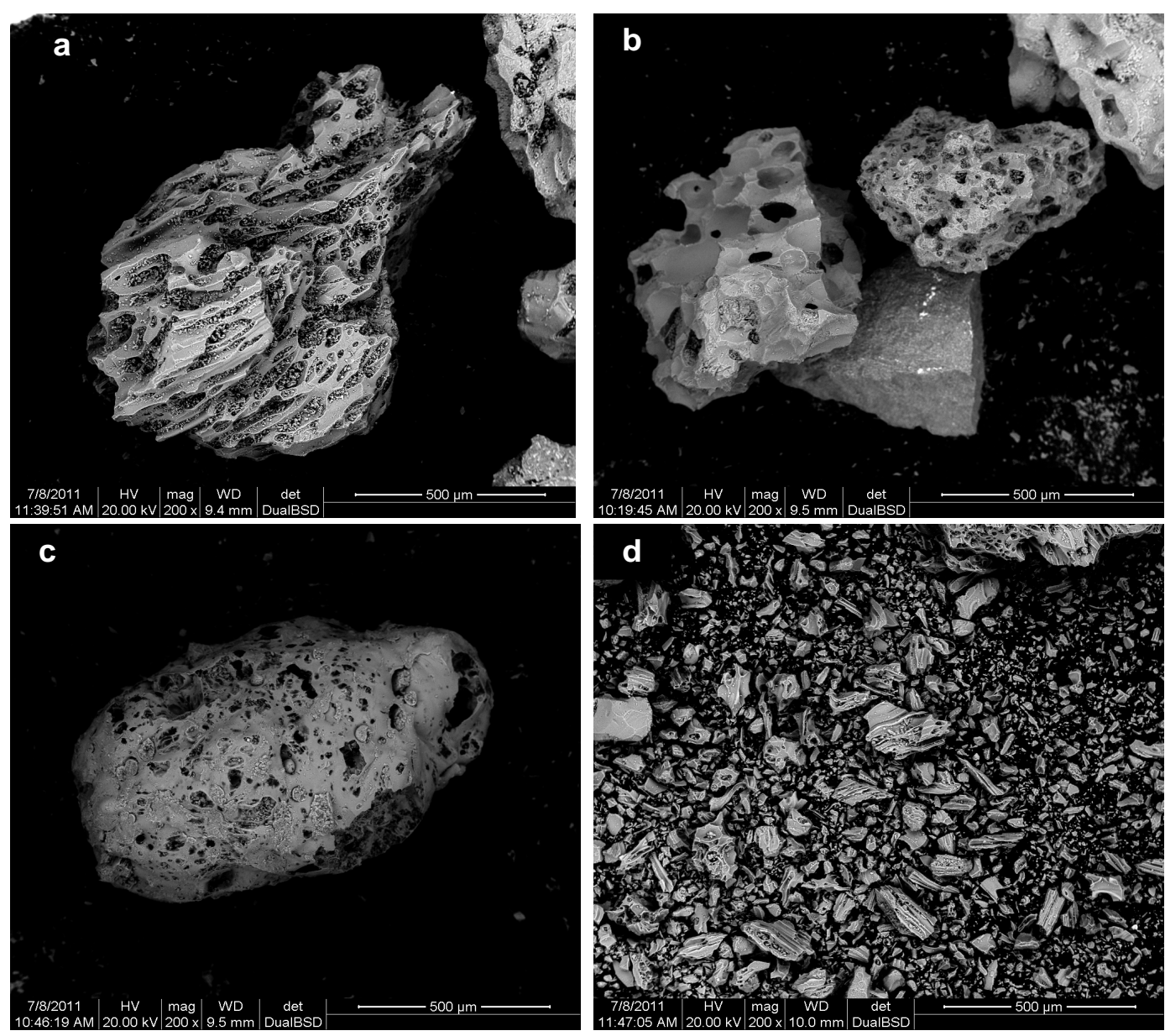

Figure 3. SEM micrographs of Bariloche samples: (a) VGLC (200×, $500 \mu \mathrm{m})$; (b) DP (200×, $500 \mu \mathrm{m})$; (c) $\mathrm{CP}(200 \times, 500 \mu \mathrm{m})$ and $(\mathrm{d})$ dust $(200 \times, 500 \mu \mathrm{m})$.

Table 3. SEM-EDS chemical data of pyroclastic material collected in Bariloche (Argentina) the first day of eruption and classified according to: volcanic glass light-color (VGLC), dark particles (DP), covered particles (CP).

\begin{tabular}{|c|c|c|c|c|c|c|c|c|c|c|c|}
\hline \% oxide & $\begin{array}{c}\text { B4 } \\
\text { bulk }\end{array}$ & $\begin{array}{l}\text { VGLC } \\
\text { B4.18 }\end{array}$ & $\begin{array}{l}\text { VGLC } \\
\text { B4.20 }\end{array}$ & $\begin{array}{l}\text { VGLC } \\
\text { B4.23 }\end{array}$ & $\begin{array}{c}\text { DP } \\
\text { B4.18 }\end{array}$ & $\begin{array}{c}\text { DP } \\
\text { B4.20 }\end{array}$ & $\begin{array}{c}\mathrm{DP} \\
\mathrm{B} 4.23\end{array}$ & $\begin{array}{c}\text { CP1 } \\
\text { B4.18 }\end{array}$ & $\begin{array}{c}\text { CP2 } \\
\text { B4.20 }\end{array}$ & $\begin{array}{c}\text { CP3 } \\
\text { B4.23 }\end{array}$ & $\begin{array}{c}\text { fine } \\
\text { crystals }\end{array}$ \\
\hline $\mathrm{SiO}_{2}$ & 64.38 & 68.48 & 68.86 & 69.24 & 57.62 & 56.99 & 56.95 & 56.89 & 52.60 & 52.14 & 60.05 \\
\hline $\mathrm{Al}_{2} \mathrm{O}_{3}$ & 14.55 & 14.13 & 14.21 & 14.11 & 14.69 & 15.40 & 16.75 & 15.73 & 15.33 & 15.19 & 25.67 \\
\hline $\mathrm{Na}_{2} \mathrm{O}$ & 5.79 & 5.71 & 5.70 & 5.77 & 4.61 & 4.00 & 4.69 & 3.35 & 3.42 & 4.24 & 5.89 \\
\hline $\mathrm{K}_{2} \mathrm{O}$ & 2.47 & 2.96 & 2.91 & 2.99 & 1.82 & 1.44 & 1.19 & 1.11 & 1.16 & 0.49 & 0.74 \\
\hline $\mathrm{CaO}$ & 2.90 & 1.69 & 1.00 & 1.62 & 5.34 & 7.02 & 6.65 & 7.01 & 7.08 & 9.03 & 7.65 \\
\hline $\mathrm{MgO}$ & 1.30 & 0.87 & 0.97 & 1.27 & 2.19 & 3.40 & 2.75 & 3.85 & 3.86 & 3.10 & nd \\
\hline $\mathrm{FeO}$ & 7.82 & 6.17 & 5.93 & 4.72 & 11.30 & 10.40 & 9.73 & 9.77 & 13.18 & 12.09 & nd \\
\hline $\mathrm{TiO}_{2}$ & 0.65 & nd & 0.42 & 0.28 & 2.41 & 1.35 & 1.29 & 1.23 & 2.37 & 2.16 & nd \\
\hline $\mathrm{SO}_{3}$ & 0.03 & nd & nd & nd & nd & nd & nd & 0.54 & 0.25 & nd & nd \\
\hline $\mathrm{Cl}_{2} \mathrm{O}$ & 0.11 & nd & nd & nd & nd & nd & nd & 0.35 & 0.75 & 1.55 & nd \\
\hline \multicolumn{12}{|l|}{ Ratio } \\
\hline $\mathrm{SiO}_{2} / \mathrm{Al}_{2} \mathrm{O}_{3}$ & 4.42 & 4.84 & 4.84 & 4.91 & 3.92 & 3.70 & 3.40 & 3.62 & 3.43 & 3.43 & 2.33 \\
\hline $\mathrm{SiO}_{2} / \mathrm{FeO}$ & 8.23 & 11.09 & 11.61 & 14.67 & 5.10 & 5.48 & 5.85 & 5.82 & 3.99 & 4.31 & - \\
\hline $\mathrm{SiO}_{2} / \mathrm{CaO}$ & 22.20 & 40.52 & 68.86 & 42.74 & 10.73 & 8.12 & 8.56 & 8.12 & 7.43 & 5.77 & 7.84 \\
\hline
\end{tabular}


The smallest particles (average size $\sim 10 \mu \mathrm{m}$ ) were essentially derived from the disaggregation of solidified magma. It is known that this type of materials is more abundant in Si-rich magmas than in Fe-rich magmas [16]. SEM microscopy of Figure 3(d) reveals that they were morphologically different (elongated and fluidal, irregular and sharp fragments of glassy material and crystals) but chemically with silica predominance. The last column of Table 3 gives main results of some small crystals selected from the glassy matrix.

It is interesting to remark that the two types of suggested paths play an important role in the degassing regime, manifested through the form, size and amount of vesicles in particles. Hence, the higher residence time of the magma in the lateral conduit could be related to a higher loss of volatiles, with viscosity increase. Contrarily, the minor residence time in the vertical conduit contributed to low degassing and low viscosity. So, the magmatic column was constituted by different types of particles.

The $\mathrm{SiO}_{2} / \mathrm{Al}_{2} \mathrm{O}_{3}, \mathrm{SiO}_{2} / \mathrm{FeO}$ and $\mathrm{SiO}_{2} / \mathrm{CaO}$ rates for VGLC, DP and CP particles presented defined ranges: the $\mathrm{SiO}_{2} / \mathrm{Al}_{2} \mathrm{O}_{3}$ ratio was similar for CP and DP (3.4 - 3.9) and higher for VGLC. The $\mathrm{SiO}_{2} / \mathrm{FeO}$ and $\mathrm{SiO}_{2} / \mathrm{CaO}$ ratios increased in the order CP $<$ DP $<$ VGLC whereas the presence of titanium was associated to Fe-rich particles (DP and CP).

Elements as $\mathrm{S}$ and $\mathrm{Cl}$ were found in the covered particles, showing also variations in gases emitted. However, it was not possible to identify the presence of salts by spectroscopic techniques. Results observed in the first column of Table 3 (bulk material) resemble to that of VGLC samples, in agreement with the predominance of clear pumice material. From chemical analysis it is possible to estimate that in the first day of eruption the VGLC proportion is $\sim 70 \%$. These samples also displayed an excess of monovalent cations ( $\mathrm{Na}>\mathrm{K}$ ), which can be attributed to several factors: a gradual acidification of the magma, the mobility of the monovalent cations in the "forming phases" region, the development or dragging of small silicate crystalline species or exogenous processes [17]. The two colors of pumice observed for the collected materials derived from the Plinian eruption were associated to iron presence, although and according to Castro et al. [12], both materials represent the same original magma source differing in the two diverse ascent conditions.

XRD patterns of the VGLC fraction and darker samples (CP and DP) were poorly crystalline as it is observed in Figure 4. Amorphous matrixes were characterized by a broad band in the $20^{\circ}-30^{\circ}$ region of $2 \theta$, although signals of crystalline phases could be suggested in higher proportion for the dark particles.

The finest material, particularly located in vesicles of DP particles, was obtained by washing and stirring with water and analyzed by XRD [18]. Although the composition was particularly glassy, the presence of crystalline $\mathrm{Na}-\mathrm{Ca}$ aluminosilicates was identified from the intense line in the $28^{\circ}$ of $2 \theta$ region (for example PDF 78-0434 for plagioclase labradorite-type or PDF 83-1939 for andesine-type, depending on the Na/Ca ratio) [18]. RX patterns revealed also the presence of quartz and magnetite-type mixed oxide $\left(\mathrm{Fe}_{3} \mathrm{O}_{4}\right.$ and/or Ti-Fe substituted magnetite phase: PDFs 86-1361, 80-0390) [18]. The low proportion of crystalline aluminosilicates affected only slightly the matrix composition of the bulk sample. An opposite effect is produced by Fe-Ti oxides, which as in

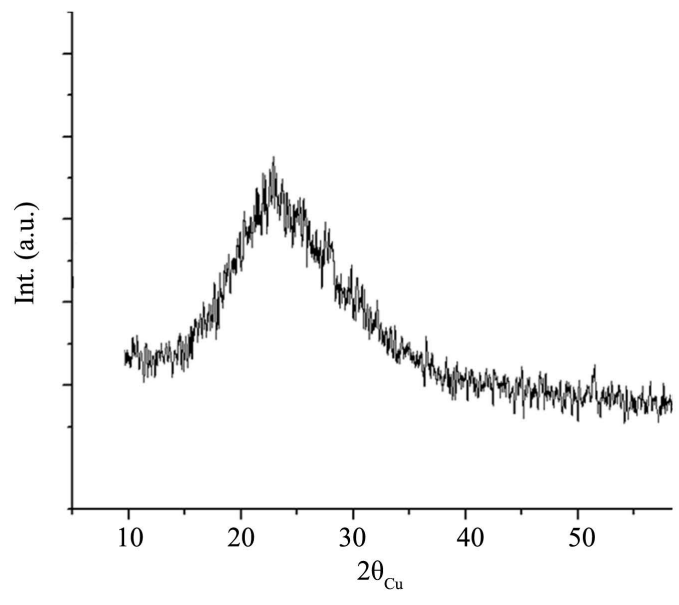

(a)

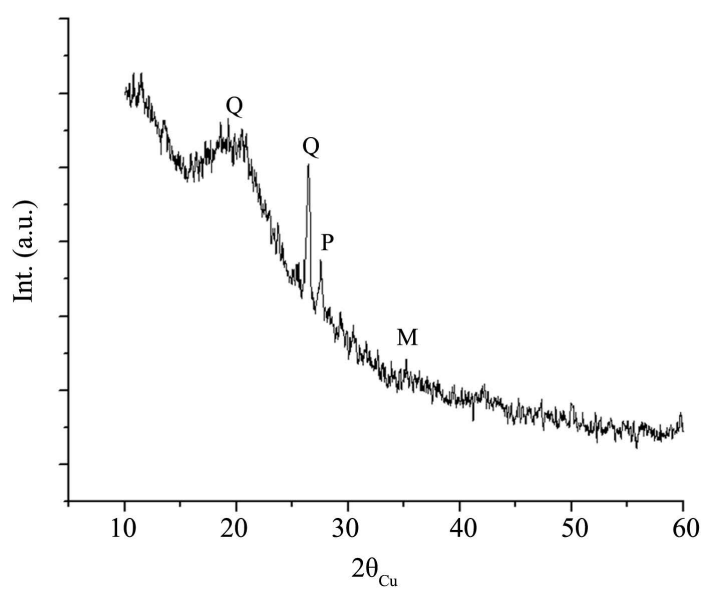

(b)

Figure 4. X-ray diffraction patterns of pumice particles: a) VGLC and b) DP (Q quartz, P plagioclase, M magnetite). 
tergrowth clusters are enclosed in the dark vesicular particles, mainly generated close to the vent of the shorter conduit, from rheological properties of the melted magma [12].

In relation to CP particles, it is interesting to remark some reported hypothesis about the surface reaction between volatiles and ash [17] [19]-[21]. In fact, according to literature [22] [23], the interaction process occurs in different zones of temperature.

The condensation zone happens at a temperature below $338^{\circ} \mathrm{C}$ [17]. The adsorption of volcanic salt aerosols has been suggested as a formation mechanism of soluble compounds on the surface ash [19]-[21]. Further dissolution process can preferentially remove these compounds; so, its lifetime depends on chemical processes during the eruption evolution or by the post deposition.

The washing treatment of coated particles (CP) was done in order to analyze the removal of soluble compounds at surface level and to investigate the under-coating part of the grains. Results shown in Table 4 and Figure 5 suggested interesting surface chemical modifications. The following is observed: the elimination of sulfur and chlorine and a significant iron decrease of iron ( 20\%) with slight variations in the alkaline and alkaline-earth elements, leaving the vesicles clearly exposed, with a composition similar to that given in Table 3 for DP particles.
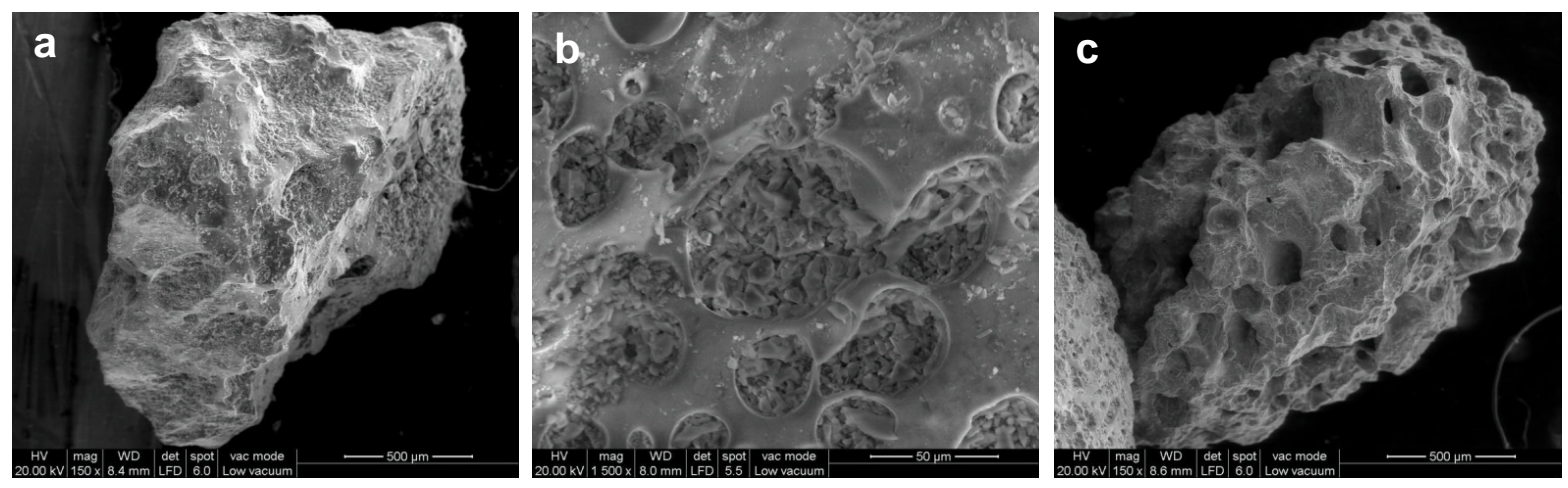

Figure 5. SEM of CP particles (a) original 150×, $500 \mu \mathrm{m}$; (b) detail of original CP 1500×, $50 \mu \mathrm{m}$ and (c) washed CP $150 \times$, $500 \mu \mathrm{m}$.

Table 4. EDS chemical analysis of original and washed CP particles.

\begin{tabular}{ccc}
\hline \% oxide & CP original & CP washed \\
$\mathrm{SiO}_{2}$ & 55.20 & 57.88 \\
$\mathrm{Al}_{2} \mathrm{O}_{3}$ & 15.70 & 15.44 \\
$\mathrm{Na}_{2} \mathrm{O}$ & 3.31 & 4.86 \\
$\mathrm{~K}_{2} \mathrm{O}$ & 1.32 & 1.39 \\
$\mathrm{CaO}$ & 6.24 & 6.03 \\
$\mathrm{MgO}$ & 4.20 & 3.25 \\
$\mathrm{FeO}$ & 12.19 & 9.56 \\
$\mathrm{TiO}_{2}$ & 1.42 & 1.59 \\
$\mathrm{SO}_{3}$ & 0.17 & nd \\
$\mathrm{Cl}_{2} \mathrm{O}$ & 0.25 & nd \\
$\mathrm{Ratio}$ & & \\
$\mathrm{SiO}_{2} / \mathrm{Al}_{2} \mathrm{O}_{3}$ & 3.52 & 3.75 \\
$\mathrm{SiO}_{2} / \mathrm{FeO}$ & 4.53 & 6.05 \\
$\mathrm{SiO}_{2} / \mathrm{CaO}$ & 8.85 & 9.60 \\
\hline
\end{tabular}


From the analysis of dark particles, the presence of Fe-Ti geothermometers [24], is in agreement with the temperature ranged between 923 and $865^{\circ} \mathrm{C}$, as it is reported by Castro et al. for the magma storage [12]. It is also known that magnetite is a stable mineral species in a large temperature range, yet in moderate reducing conditions. So, in magmas, magnetite can act as a favorable site for heterogeneous nucleation of bubbles [25]. The bubble-magnetite aggregate process leads to the formation of a vesicular material with big cavities respect to those observed in the VGLC material where the catalytic action of iron is absent. The enclosed microcrystalline phases are presumably associated to lower effects of degassing and consequently minor fragmentation, unlike the behavior observed for the VGLC particles formed at lower temperature by cooling of a melt enriched in alkalis.

Raman micro-probe was useful to reveal the presence of microcrystals. However it was unsuccessful to analyze the vitreous material by two reasons: it absorbs water easily and the structural disorder affects the resolution. Raman spectrum of Figure 6 corresponds to crystalline aluminosilicates (pyroxene and plagioclase) selected under optical microscope. In fact, pyroxene is characterized by the presence of three signals at 997, 667 and 322 $\mathrm{cm}^{-1}$ whereas plagioclase (labradorite) shows a typical and strong line centered $\sim 510 \mathrm{~cm}^{-1}$ and weak Raman signals close $1000 \mathrm{~cm}^{-1}$ [26] [27]. The experimental signals of Figure 6, located at 999, 664, 530, 380 and 325 $\mathrm{cm}^{-1}$, were in agreement with the crystal phases suggested by XRD.

The relationship between the elapsed time since the eruption start and the chemical composition of the collected ash is observed in Table 5. Data correspond to bulk materials collected in Bariloche the days subsequent

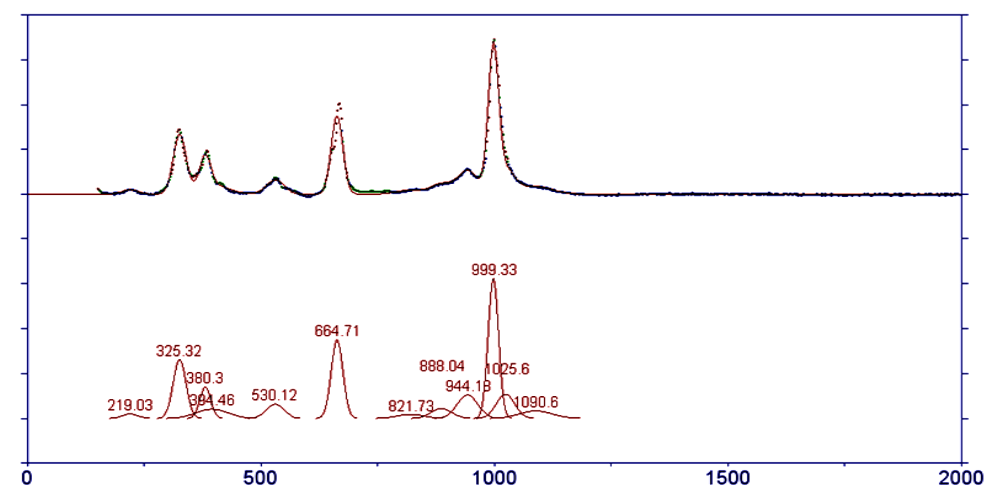

Figure 6. Raman microprobe of crystalline particles.

Table 5. EDS chemical results for bulk samples collected in Bariloche after the second eruption phase (10-12 June). Data for B4 and B7 bulk samples are included as reference.

\begin{tabular}{|c|c|c|c|c|}
\hline (\% oxide) & B4 bulk & B7 & B10 & B12 \\
\hline $\mathrm{SiO}_{2}$ & 64.38 & 69.24 & 69.12 & 70.08 \\
\hline $\mathrm{Al}_{2} \mathrm{O}_{3}$ & 14.55 & 14.11 & 13.92 & 13.91 \\
\hline $\mathrm{Na}_{2} \mathrm{O}$ & 5.79 & 5.77 & 5.21 & 5.37 \\
\hline $\mathrm{K}_{2} \mathrm{O}$ & 2.47 & 2.99 & 3.12 & 2.90 \\
\hline $\mathrm{CaO}$ & 2.90 & 1.62 & 1.63 & 1.88 \\
\hline $\mathrm{MgO}$ & 1.30 & 1.27 & 0.46 & 0.60 \\
\hline $\mathrm{FeO}$ & 7.82 & 4.80 & 5.78 & 4.70 \\
\hline $\mathrm{TiO}_{2}$ & 0.65 & 0.28 & 0.69 & 0.56 \\
\hline $\mathrm{SO}_{3}$ & 0.03 & nd & nd & nd \\
\hline $\mathrm{Cl}_{2} \mathrm{O}$ & 0.11 & nd & nd & nd \\
\hline \multicolumn{5}{|l|}{ Ratio } \\
\hline $\mathrm{SiO}_{2} / \mathrm{Al}_{2} \mathrm{O}_{3}$ & 4.42 & 4.94 & 5.0 & 5.0 \\
\hline $\mathrm{SiO}_{2} / \mathrm{FeO}$ & 8.23 & 16.10 & 12.0 & 14.9 \\
\hline $\mathrm{SiO}_{2} / \mathrm{CaO}$ & 22.20 & 42.74 & 42.4 & 22.7 \\
\hline
\end{tabular}


to the second phase of the volcanic-event (B10 and B12 samples). Values obtained June $4^{\text {th }}$ and $7^{\text {th }}$ (first eruptive phase) were included for comparative purposes.

The decrease of Fe content was clearly observed with the evolution of volcanic activity. This effect can be related to the energy magnitude of eruptive phases, the eruption character (explosive-effusive) and the different mobilization of particles in the plume according to size and density (lower than $0.8 \mathrm{~g} \cdot \mathrm{cm}^{-1}$ ).

Figure 7 shows a profile of deposited material between June 4 and November 8 (2011) at the Cardenal Samore Pass $\left(40^{\circ} 42^{\prime} 43^{\prime \prime S}-71^{\circ} 56^{\prime} 38^{\prime \prime} \mathrm{O}\right)$ close $20 \mathrm{~km}$ to the source. From the base to the top, diminution in the coarse material as well as in the fraction of darker particles were observed. Finer and clearer material dominated the surface level.

Results of physicochemical characterization of different types of particles ejected from the PCCVC eruption during first days of eruption could be explained from the explosive-effusive eruptive scheme given by Castro et $a l$. [12]. In this sense, the differential ascent and decompression of magma could be associated to a differential degassing and fragmentation. It can be suggested that a fast ascent, avoiding the fragmentation and the loss of volatiles, occurred preferentially in the shorter vertical conduit, with magma solidification close to the vent. This situation would have favored a chemical composition enriched in iron and titanium, necessary for the formation of DP and CP particles, observed during the initial phase of eruption. Contrarily, the kinematic of the lateral path (dike-type flow field), involving a longer distance between the stored-magma and the vent, could have also contributed to a gradual degassing and a viscosity increase of the melt. This scheme, associated to the effusive regime (allowed by a permeable environment for an effective open-system degassing), facilitated the lava output through formation of fissures.

Regarding to the distance from the source, the relationship among samples of close and far locations to the volcano allowed obtaining additional conclusions. Table 6 shows comparatively the EDS data of bulk samples collected at different distances from the source: the closer locality (Villa La Angostura, June $5^{\text {th }}$ ) and the farthest one (Puerto Madryn, June $6^{\text {th }}$ ). Values are related to those of Table 3.

Pyroclastic materials from Villa La Angostura presented variable size: coarse particles, shown in Figure 8(a) and Figure 8(b), have a morphology similar to that observed in Bariloche samples, whereas the finest particles, lower than $64 \mu \mathrm{m}$ (Figure 8(c)), are comparable to that collected in Puerto Madryn (Figure 8(d)) where the material is an homogeneous dust, predominantly vitreous with sharp edges. Chemically it is characterized by rhyolitic composition $\left(\mathrm{SiO}_{2} \sim 70 \%\right)$, the $\mathrm{Cl}$ and $\mathrm{S}$ absence as well as a marked iron diminution. These aspects can be correlated to the height of the volcanic plume, meteorological processes, mass flux of particles injected in the at

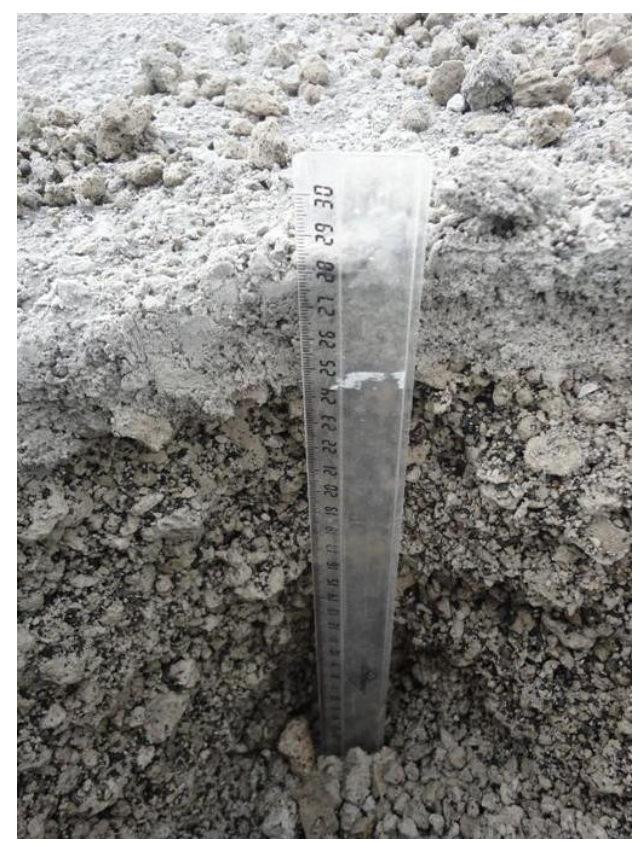

Figure 7. Profile of deposited pyroclastic material after 5 months of the eruption. 


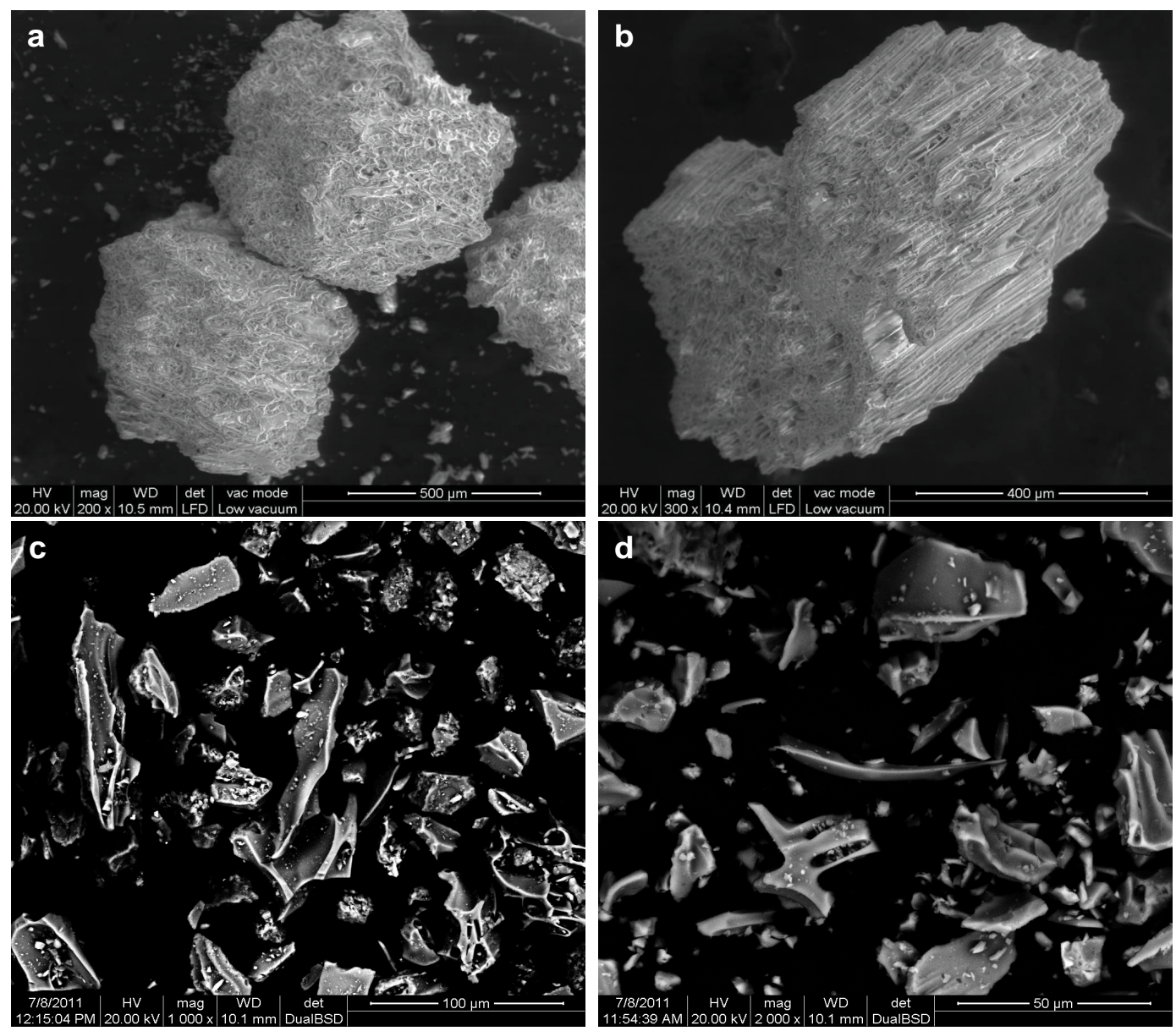

Figure 8. SEM micrographs of simples: (a) 200×, $500 \mu \mathrm{m}$; (b) $300 \times, 400 \mu \mathrm{m}$ and (c) $1000 \times 100 \mu \mathrm{m}$ of Villa La Agostura; (d) $2000 \times, 50 \mu \mathrm{m}$ of Puerto Madryn.

mosphere and the material density.

Finally, the last column of Table 6 gives EDS values for material collected from the surface of soils of Villa La Angostura, five month after the event (Figure 7). Results revealed that environmental conditions affected the chemical composition. Thus, the $\mathrm{SiO}_{2}$ content not only increases with the distance but also with the deposition time.

Raman spectroscopy contributed also to show the weathering process. In fact, unlike that observed in initial sampling, the material named LANov2011 revealed that magnetite was partially transformed in hematite (typical lines below $550 \mathrm{~cm}^{-1}$ ), although the most conspicuous Raman line useful for the magnetite identification at $665 \mathrm{~cm}^{-1}$ was yet observed [26] [28] [29].

\section{Conclusions}

Physical and chemical characterization of particles ejected from PCCVC and collected during the first days of the event at different distances of the source allows to clearly distinguishing a tendency in the deposition of grain-size fractions contained in the ash, manifested by a progressive increase in fine depositions with time for each of the recognized eruptive phases. Two types of materials are undoubtedly differentiated. The more abundant is constituted by glassy pumice rhyolitic and fluidal particles, showing a typical vesicular texture, chemically characterized by a very low content of iron and titanium and high values of alkaline elements. The proportion of this pyroclastic material is close to $70 \%$ in the initial explosive phase. The material found in minor proportion ( $\sim 30 \%)$ in similar period is constituted by dark color particles rich in $\mathrm{Fe}$ and $\mathrm{Ti}$, with different shape and texture respect to the clear glassy pumice. 
Table 6. EDS chemical analysis of bulk samples collected in Villa La Angostura (June $5^{\text {th }}$ and November $8^{\text {th }}$ ) Puerto Madryn (June $6^{\text {th }}$ ). Bariloche sample is included as reference.

\begin{tabular}{|c|c|c|c|c|}
\hline \% oxide & $\begin{array}{c}\text { PM } \\
5 \mathrm{Jun} \\
635 \mathrm{~km}\end{array}$ & $\begin{array}{c}\text { B } \\
4 \text { Jun. } \\
75 \mathrm{~km}\end{array}$ & $\begin{array}{c}\text { LA } \\
5 \mathrm{Jun} \\
40 \mathrm{~km}\end{array}$ & $\begin{array}{c}\text { LA } \\
\text { Nov. } \\
40 \mathrm{~km}\end{array}$ \\
\hline $\mathrm{SiO}_{2}$ & 70.08 & 64.38 & 62.10 & 67.99 \\
\hline $\mathrm{Al}_{2} \mathrm{O}_{3}$ & 13.91 & 14.55 & 14.81 & 16.32 \\
\hline $\mathrm{Na}_{2} \mathrm{O}$ & 2.52 & 5.79 & 5.77 & 5.07 \\
\hline $\mathrm{K}_{2} \mathrm{O}$ & 2.19 & 2.47 & 2.31 & 1.61 \\
\hline $\mathrm{CaO}$ & 1.88 & 2.90 & 2.78 & 2.30 \\
\hline $\mathrm{MgO}$ & 1.04 & 1.30 & 2.37 & 2.27 \\
\hline $\mathrm{FeO}$ & 4.00 & 7.82 & 8.51 & 4.74 \\
\hline $\mathrm{TiO}_{2}$ & 0.56 & 0.65 & 0.70 & 0.70 \\
\hline $\mathrm{SO}_{3}$ & nd & 0.03 & 0.23 & nd \\
\hline $\mathrm{Cl}_{2} \mathrm{O}$ & nd & 0.11 & 0.42 & nd \\
\hline \multicolumn{5}{|l|}{ Ratio } \\
\hline $\mathrm{SiO}_{2} / \mathrm{Al}_{2} \mathrm{O}_{3}$ & 5.03 & 4.42 & 4.19 & 4.17 \\
\hline $\mathrm{SiO}_{2} / \mathrm{FeO}$ & 17.52 & 8.23 & 7.29 & 14.34 \\
\hline $\mathrm{SiO}_{2} / \mathrm{CaO}$ & 37.27 & 22.20 & 22.42 & 29.56 \\
\hline
\end{tabular}

On the other hand, for clear glassy particles, the presence of the large number of aligned vesicles with low thickness walls, not only permits an easy fragmentation but also the absence of the occluded crystalline phases. This can be attributed to the contribution of an ascent magma path by a lateral and longer conduit, which modifies the rheologycal behavior of melt. These aspects are related to a slow transport of a highly viscose melt, associated to lava production in an effusive process.

The physical and chemical characteristics of dark and vesiculated particles suggest that they were formed from magma that quickly ascends cooling at a distance close enough to the vent. This is concomitant with the short distance from the stored magma at elevated temperature, a short residence time and lower viscosity. The high Fe and Ti content could be associated to the low degassing and the presence of iron-oxide phases as well as high-temperature crystalline aluminosilicates occluded in the vesicles. On the other hand, dark particles seem to be more effective materials for the interaction with emitted gases in the upper part of the column.

Results obtained with ash collected during the two firsts phases of PCCVC volcano eruption constitute another feature to be considered in the explosive-effusive hybrid process by which the pyroclastic material occurred simultaneously with a lava flow, following the model proposed by Castro et al. [12] and Schipper et al. [13].

From a practical point of view, both the ash from the first phases of volcanic activity as those affected by the climatic and depositional conditions, are cost-effective raw materials with potentiality in environmental, agronomic and catalytic fields.

\section{Acknowledgements}

The work was done by financial support of ANPCyT BID 2011 PICT-2186 Argentina and CUIA (Italy-Argentina).

\section{References}

[1] Singer, B.S., Jicha, B.R., Harper, M.A., Naranjo, J.A., Lara, L.E. and Moreno Roa, H. (2008) Eruptive History, Geochronology and Magmatic Evolution of the Puyehue-Cordon Caulle Volcanic Complex, Chile. Geological Society of America Bulletin, 120, 599-618. http://dx.doi.org/10.1130/B26276.1

[2] Violante, R. and Rovere, E. (2005) Los sedimentos de la Plataforma Submarina y su relación con el volcanismo andino neógeno. XVI Congreso Geológico Argentino, La Plata, Septiembre de 2005, 239-246. 
[3] (2011) SERNAGEOMIN Reportes especiales de actividad volcánica complejo volcánico puyehue-Cordón Caulle. http://www.sernageomin.cl/volcan.php?iId=38

[4] Raga, G.B., Baumgardner, D., Ulke, A., Torres Brizuela, M. and Kucienska, B. (2013) The Environmental Impact of the Puyehue-Cordon Caulle 2011 Volcanic Eruption on Buenos Aires. Natural Hazards and Earth System Sciences, 13, 2319-2330. http://dx.doi.org/10.5194/nhess-13-2319-2013

[5] Schaper K., Thomas, W., Peters, A., Ries, L., Obleitner, F., Schnelle-Kreis, J., Birmili, W., Diemer, J., Fricke, W., Junkermann, W., Pitz, M., Emeis, S., Forkel, R., Suppan, P., Flentje, H., Gilge, S., Wichmann, H., Meinhardt, F., Zimmermann, R., Weinhold, K., Soentgen, J., Munkel, C., Freuer, C. and Cyrys, J. (2011) Influences of the 2010 Eyjafjallajokull Volcanic Plume on Air Quality in the Northern Alpine Region. Atmospheric Chemistry and Physics, 11, 8555-8575. http://dx.doi.org/10.5194/acp-11-8555-2011

[6] Grainger, R.G., Peters, D.M., Thomas, G.E., Smith, A., Siddans, R., Carboni, E. and Dudhia, A. (2013) Measuring Volcanic Plume and Ash Properties from Space. Geological Society London Special Publications, 380, $293-320$. http://dx.doi.org/10.1144/SP380.7

[7] Mulena, C., Allende, D. and Puliafito, E. (2013) Modelado de la última erupcion volcanica del Complejo Volcánico Puyehue-Cordon Caulle. Pyroclastic Flow Journal of Geology, 3, 14-22.

[8] Horwell, C.J. and Baxter, P. (2006) The Respiratory Health Hazards of Volcanic Ash: A Review for Volcanic Risk Mitigation. Bulletin of Volcanology, 69, 1-24. http://dx.doi.org/10.1007/s00445-006-0052-y

[9] Horwell, C.J., Le Blond, J.S., Michnowicz, S.A.K. and Cressey, G. (2010) Cristobalite in a Rhyolitic Lava Dome: Evolution of Ash Hazard. Bulletin of Volcanology, 72, 249-253. http://dx.doi.org/10.1007/s00445-009-0327-1

[10] Scasso, R. and Carey, S. (2005) Morphology and Formation of Glassy Volcanic Ash from the August 12-15 1991 Eruption of Hudson Volcano, Chile. Latin American Journal of Sedimentology and Basin Analysis, 12, 3-21.

[11] Giordano, D., Russell, J.K. and Dingwell, D.B. (2008) Viscosity of Magmatic Liquid: A Model. Earth and Planetary Science Letters, 271, 123-134. http://dx.doi.org/10.1016/j.epsl.2008.03.038

[12] Castro, J., Schipper, C., Mueller, S., Militzer, A., Amigo, A., Silva Parejas, C. and Jacob, D. (2013) Storage and Eruption of Near-Liquidus Rhyolite Magma at Cordón Caulle, Chile. Bulletin of Volcanology, 75, 1-17.

[13] Schipper, C.I., Castro, J.M., Tuffen, H., James, M.R. and How, P. (2013) Shallow Vent Architecture during Hybrid Explosive-Effusive Activity at Cordon Caulle (Chile 2011-2012): Evidence from Direct Observations and Pyroclastic Textures. Journal of Volcanology and Geothermal Research, 262, 25-37. http://dx.doi.org/10.1016/j.jvolgeores.2013.06.005

[14] Bermudez, A. and Delpino, D. (2011) La actividad del complejo volcanic Puyehue-Corcón Caulle y su impacto sobre el territorio de la República Argentina. Segundo Informe. CONICET. (Personal Communication) http://www.conicet.gov.ar/new_noticias/noticias.php?id_noticia=7295\&nota_completa=yes\&tipo=6

[15] Tuffen, H., James, M.R., Castro, J.M. and Schipper, C.I. (2013) Exceptional Mobility of on Advancing Rhyolitic Obsidian Flow at Cordón Caulle Volcano in Chile. Nature Communications, 4, 2709. http://dx.doi.org/10.1038/ncomms3709

[16] Rose, W.I. and Durand, A.J. (2009) Fine Ash Content of Explosive Eruptions. Journal of Volcanology and Geothermal Research, 186, 32-39. http://dx.doi.org/10.1016/j.jvolgeores.2009.01.010

[17] Witham, C.S., Openheimer, C. and Horwell, C. (2005) Volcanic Ash Leachates: A Review and Recommendations for Sampling Methods. Journal of Volcanology and Geothermal Research, 141, 229-326. http://dx.doi.org/10.1016/j.jvolgeores.2004.11.010

[18] Botto, I.L., Canafoglia, M.E., Gazzoli, D. and Gonzalez, M.J. (2013) Spectroscopic and Microscopic Characterization of Volcanic Ash from Puyehue-(Chile) Eruption. Preliminary Approach for the Application in the Arsenic Removal. Journal of Spectroscopy, 2013, Article ID: 254517.

[19] Delmelle, P., Gerin, P. and Oskarsson, N. (1980) Surface and Bulk Studies of Leached and Unleached Volcanic Ashes. EOS, Transaction American Geophysical Union, 81, F1311.

[20] Delmelle, P., Lambert, M., Dufresne, Y., Gerin, P. and Oskarsson, N. (2007) Gas Aerosol-Ash Interaction in Volcanic Plumes: New Insights from Surface Analysis of Fine Ash Particles. Earth and Planetary Science Letters, 259, 159-170. http://dx.doi.org/10.1016/j.epsl.2007.04.052

[21] Gislason, S.R., Hassenkamb, T., Nedelb, S., Bovetb, N., Eiriksdottira, E.S., Alfredssona, H.A., Hemb, C.P. and Baloghb, Z.I. (2011) Characterization of Eyjafjallajökull Volcanic Ash Particles and a Protocol for Rapid Risk Assessment. Proceedings of the National Academy of Sciences, 108, 7307-7312. http://dx.doi.org/10.1073/pnas.1015053108

[22] Rose Jr., W.I. (1977) Scavenging of Volcanic Aerosol by Ash: Atmospheric and Volcanologic Implications. Geology, 5, 621-624. http://dx.doi.org/10.1130/0091-7613(1977)5<621:SOVABA>2.0.CO;2

[23] Oscarsson, N. (1980) The Interaction between Volcanic Gases and Tephra: Fluorine Adhering to Tephra of the 1970 Hekla Eruption. Journal of Volcanism and Geothermal Research, 8, 251-266. 
http://dx.doi.org/10.1016/0377-0273(80)90107-9

[24] Ghiorso, M.S. and Evans, B.W. (2008) Thermodynamics of Rhombohedral Oxide Solid Solutions and a Revision of the Fe-Ti Two-Oxide Geothermometer and Oxygen-Barometer. American Journal of Science, 308, 957-1039. http://dx.doi.org/10.2475/09.2008.01

[25] Edmonds, M., Brett, A., Herd, R., Humphrey, M. and Woods, A. (2014) Magnetite-Bubble Aggregates at Mixing Interfaces in Andesite Magma Bodies. In: Zellmer, G.F., Edmonds, M. and Straub, S.M., Eds., The Role of Volatiles in the Genesis, Evolution and Eruption of Arc Magmas, Geological Society, London, 410.

[26] Haskin, L., Wang, A., Rockow, K., Jolliff, B., Korotev, R. and Viskupic, K. (1997) Raman Spectroscopy for Mineral Identification and Quantification for in Situ Planetary Surface Analysis: A Point Count Method. Journal of Geophysical Research, 102, 19293-19306. http://dx.doi.org/10.1029/97JE01694

[27] Sidorov, T. (2007) Raman Spectra and Molecular Structure of Silicates. Russian Journal of Inorganic Chemistry, 52, 1586-1594. http://dx.doi.org/10.1134/S0036023607100191

[28] Das, S. and Hendry, M.J. (2011) Application of Raman Spectroscopy to Identify Iron Minerals Commonly Found in Mine Wastes. Chemical Geology, 290, 101-108. http://dx.doi.org/10.1016/j.chemgeo.2011.09.001

[29] Hanesch, M. (2009) Raman Spectroscopy of Iron Oxides and (Oxy)hydroxides at Low Laser Power and Possible Applications in Environmental Magnetic Studies. Geophysical Journal International, 177, 941-948. http://dx.doi.org/10.1111/j.1365-246X.2009.04122.x 